\title{
PELAKSANAAN PROGRAM GERAKAN LITERASI SEKOLAH (GLS) DI SDN 014 KOTA BANGUN
}

\author{
Devi Yuliyati ${ }^{1}$, Febrina Dafit ${ }^{1}$ \\ ${ }^{1}$ Universitas Islam Riau, Pekanbaru \\ *Corresponding Address: deviyulianti22@gmail.com
}

Naskah diterima: 17 September 2021| Disetujui: 6 Oktober 2021 | Diterbitkan: 8 Oktober 2021

\begin{abstract}
This study aims to determine the implementation of the School Literacy Movement (GLS) program at SDN 014 Kota Bangun, Tapung Hilir District, Kampar Regency. The research method used is descriptive qualitative using interview, observation and documentation techniques with predetermined informants, namely the principal, vice principal, class teacher, and student representatives. The results of this study indicate that literacy activities at SDN 014 Kota Bangun cannot be said to be a entrenched habit, but have been included in efforts to foster a literacy culture. Although there have been other efforts in the form of literacy development and learning in each subject as an advanced stage of the implementation of the school literacy program carried out by teachers, it has not been carried out consistently and sustainably. interest. There are supporting factors, including good cooperation between schools and parents, even parents also provide input in making reading corners. There are inhibiting factors, among others, regarding the facilities and infrastructure to support literacy activities, the problem of participation of some teachers, and the activity of some classes.
\end{abstract}

Keywords: School literacy movement, elementary school

Abstrak: Penelitian ini bertujuan untuk mengetahui pelaksanaan program gerakan literasi sekolah (GLS) di SDN 014 Kota Bangun Kecamatan Tapung Hilir Kabupaten Kampar. Metode penelitian yang digunakan adalah kualitatif deskriptif dengan menggunakan teknik wawancara, observasi, dan dokumentasi dengan informan yang telah ditentukan yaitu kepala sekolah, guru kelas, dan perwakilan siswanya. Dari hasil penelitian ini menunjukkan bahwa kegiatan literasi di SDN 014 Kota Bangun belum bisa disebut sebagai kebiasaan yang membudaya, akan tetapi sudah termasuk dalam upaya menumbuhkan budaya literasi. Meskipun sudah terdapat upaya lain berupa pengembangan dan pendidikan literasi dalam setiap pelajaran sebagai tahap lanjutan dari pelaksanaan program literasi sekolah yang dilakukan oleh guru, belumlah dilakukan secara konsisten dan berkelanjutan. Dengan demikian, pelaksanaan program literasi di SDN 014 Kota Bangun masih dalam tahap pembiasaan atau penumbuhan minat. Terdapat faktor-faktor pendukung antara lain mengenai kerjasama yang baik antara sekolah dan orang tua, bahkan orang tua juga ikut memberikan masukan dalam pembuatan pojok baca. Terdapat faktor penghambat antara lain yaitu sarana dan prasarana penunjang kegiatan literasi, masalah partisipasi sebagian guru, dan keaktifan sebagian kelas.

Kata Kunci: Gerakan literasi sekolah, sekolah dasar. 


\section{PENDAHULUAN}

Pemerintah Indonesia telah mengupayakan peningkatkan budaya literasi dengan mengeluarkan Peraturan Menteri Pendidikan dan Kebudayaan. Kemendikbud Nomor 23 Tahun 2015 tentang Penumbuhan Budi Pekerti yang berisi tentang kewajiban bagi siswa SD SMP dan SMA untuk membaca dan dituangkan dalam Gerakan Literasi Sekolah (GLS) sebagai upaya untuk peningkatan minat baca siswa di Indonesia. Gerakan ini terpusat pada sekolah sebagai pusat pembelajaran dengan harapan kegiatan membaca dapat menghasilkan budaya belajar sepanjang masa. Implementasi GLS adalah dengan membaca buku di luar mata pelajaran selama 15 menit sebelum pelajaran dimulai. Kegiatan ini dilaksanakan untuk menumbuhkan minat baca siswa serta meningkatkan keterampilan membaca agar pengetahuan dapat dikuasai secara lebih baik. Materi baca dalam kegiatan ini adalah bacaan yang berisi nilai-nilai budi pekerti, berupa kearifan lokal, nasional, dan global yang disampaikan sesuai tahap perkembangan siswa.

Pengertian literasi secara sederhana dapat diartikan dengan melek huruf, kemampuan baca tulis, dan kecakapan dalam membaca dan menulis. Namun, tidak demikian untuk sekarang karena kebutuhan akan pengetahuan pada setiap individu jauh berbeda. Literasi dalam bahasa Inggris bertuliskan literacy, kata ini berasal dari bahasa Latin littera (huruf) yang memiliki definisi melibatkan penguasaan sistem-sistem tulisan dan konvensi-konvensi yang menyertainya. Literasi di masyarakat seringkali hanya dimaknai sebagai kegiatan membaca dan menulis (Hidayah, 2017). Namun sejalan dengan perkembangan zaman dan semakin besarnya tantangan yang dihadapi, pengertian literasi semakin berkembang hingga menjadi literasi informasi (information literacy). Ada juga yang mengatakan bahwa literasi merupakan kemampuan yang berkaitan dengan kegiatan membaca, berpikir, dan menulis yang bertujuan untuk meningkatkan kemampuan memahami informasi secara kritis, kreatif, dan reflektif (Anggraeni, 2019). Secara konsep, literasi dipahami lebih dari sekedar membaca dan menulis, namun mencakup keterampilan berpikir menggunakan sumbersumber pengetahuan dalam bentuk cetak, visual, digital, dan auditori. Sedangkan literasi juga bisa diartikan sebagai kemampuan membaca dan menulis (Wiedarti, 2016). Seseorang dapat disebut literat apabila telah memiliki pengetahuan untuk digunakan dalam setiap aktivitas yang menuntut fungsi literasi secara efektif dalam masyarakat dan pengetahuan yang dicapainya dengan membaca, menulis yang memungkinkan untuk dimanfaatkan bagi dirinya sendiri.

Pengertian literasi berkembang sejalan dengan perubahan waktu dan telah bergeser dari pengertian yang sempit menuju ke pengertian yang lebih luas mencakup bidang penting yang memiliki arti kemampuan atau melek teknologi, politik, berpikir kritis, dan peka terhadap lingkungan sekitar. Hal ini tentu telah berkembang dari pengertian semula yang hanya diartikan sebagai 
kemampuan membaca dan menulis. Sejalan dengan perkembangan zaman dan berkembang menurut bidang ilmunya masing-masing. Ada berbagai bidang ilmu yang menetapkan komunikasi sebagai salah satu dimensi literasi. Ini menunjukan bahwa kemampuan literasi apapun tidak dapat dipisahkan dari bidang ilmu bahasa, sebab bahasa merupakan alat utama untuk menyebarluaskan pengetahuan. Jadi, literasi memiliki makna dan implikasi dari keterampilan membaca dan menulis dasar. Berdasarkan pendapat para ahli di atas maka dapat disimpulkan bahwa literasi merupakan kemampuan membaca, menulis, berbicara, menyimak dan memanfaatkan teknologi untuk kemajuan program yang telah diterapkan.

Gerakan Literasi Sekolah lebih dari sekadar membaca dan menulis, namun dapat mengembangkan keterampilan berfikir dalam mengolah pengetahuan dari yang sudah diperoleh dalam membaca menjadi bentuk cetak, visual, digital, dan auditori. Kemampuan ini disebut sebagai Literasi Informasi. Literasi yang komprehensif dan saling terkait ini membuat seseorang mampu berkontribusi kepada masyarakat sesuai dengan kompetensi dan perannya sebagai warga negara global (global citizen). Dari enam keterampilan tersebut perlu diawali dengan literasi dini yang mencakup fonetik, alfabeta, kosakata, sadar dan memaknai materi cetak (print awareness), kemampuan menggambarkan dan menceritakan kembali (narrative skills). Oleh sebab itu, perlu diberi perhatian terhadap keberlangsungan pendidikan literasi usia dini berlanjut ke literasi dasar. Dalam pendidikan formal, peran aktif para pemangku kebijakan, yaitu kepala sekolah, guru, tenaga pendidik, dan pustakawan sangat berpengaruh untuk memfasilitasi pengembangan komponen literasi siswa. Selain itu, diperlukan juga pendekatan cara belajar-mengajar yang berpihak pada literasi bacatulis, literasi sains, literasi numerasi, literasi digital, dan literasi finansial. Sehingga kesempatan siswa berpusat pada komponen literasi yang akan menentukan kesiapan berinteraksi dengan literasi visual untuk membawa perubahan dalam lingkungan literasi.

GLS merupakan suatu gerakan yang dicanangkan oleh pemerintah dengan alasan-alasan sebagai diantaranya, keterampilan membaca siswa, Indonesia menduduki peringkat rendah, tuntutan keterampilan membaca pada abad 21 adalah kemampuan memahami informasi secara analitis, kritis, dan reflektif. Alasan selanjutnya bahwa pembelajaran di sekolah belum mampu mengajarkan kompetensi abad 21. Kemudian kegiatan membaca di sekolah perlu dikuatkan dengan pembiasan membaca di keluarga dan masyarakat. GLS menurut buku Panduan Gerakan Literasi Sekolah merupakan sebuah upaya yang dilakukan secara menyeluruh, oleh sekolah sebagai organisasi pembelajar yang warganya literat sepanjang hayat melalui pelibatan publik. Pengertian tersebut menunjukan bahwa pembiasaan literasi di sekolah membutuhkan suatu pelibatan publik yang masif untuk mensukseskan lingkungan yang literat di sekolah. GLS merupakan suatu upaya atau kegiatan yang bersifat partisipatif dengan melibatkan warga sekolah (siswa, guru, kepala sekolah, tenaga 
kependidikan, pengawas sekolah, Komite Sekolah, orang tua/wali murid), akademisi, penerbit, media massa, masyarakat (tokoh masyarakat yang dapat merepresentasikan keteladanan, dunia usaha, dan lainnya), dan pemangku kepentingan di bawah koordinasi Direktorat Jenderal Pendidikan Dasar dan Menengah Kementerian Pendidikan dan Kebudayaan (Kemendikbud). Guru mempunyai peran yang sangat fundamental dalam pelaksanaan GLS (Setyawan \& Gusdian, 2020).

Banyak sekali tantangan yang harus dihadapi untuk mewujudkan keberhasilan literasi di sekolah, baik tantangan yang berasal dari internal siswa maupun faktor eksternal. Motivasi yang rendah dari siswa untuk membudayakan membaca dan peran media sosial yang telah meracuni pada diri siswa menjadi tugas berat guru. Sehingga dapat disimpulkan bahwa GLS adalah gerakan sosial dengan dukungan kolaboratif berbagai elemen baik dari masyarakat maupun pihak sekolah dengan berupaya mewujudkan budaya literasi dikalangan pelajar serta lingkungan sekolah.

Adapun tujuan gerakan literasi sekolah berorientasi dalam menumbuhkan dan meningkatkan budaya budi pekerti dan literasi dengan terus belajar sepanjang hayat dan mengelola sekolah menjadi ladang informasi dan sarana pembelajaran yang menunjang kemampuan siswa. Pelaksanaan gerakan literasi di sekolah memiliki pedoman dalam pelaksanaannya agar program literasi menjadi lebih jelas dan terarah. Tahapan pelaksanaan GLS dimulai dari tahap pembiasaan, pengembangan, dan pembelajaran. Dari ketiga tahap tersebut saling keterkaitan. Tahap pembiasaan dilakukan dengan kegiatan membaca secara rutin untuk mencapai tahap berkembang hingga menjadi kegemaran atau cinta membaca. Tahap pengembangan adalah proses lanjutan pada tahap awal dengan berbagai stategi tertentu sesuai dengan keadaan. Kemudian yang terakhir adalah tahap pembelajaran, di mana pada tahap ini dapat kita kaitkan dengan beberapa mata pelajaran dan dapat diterapkan di dalam kelas.

SDN 014 Kota Bangun Kecamatan Tapung Hilir Kabupaten Kampar merupakan salah satu sekolah di Kecamatan Tapung Hilir Kabupaten Kampar Provinsi Riau yang menjalankan program Gerakan Literasi Sekolah. Program GLS di SDN 014 Kota Bangun pada umumnya menekankan prinsip-prinsip diantaranya tahapan pembiasaan, yaitu membiasakan siswa sejak awal untuk gemar membaca sehingga sekolah dapat memilih strategi literasi yang tepat sesuai dengan tingkatan minat siswanya. SDN 014 Kota Bangun juga menerapkan prinsip melalui program yang ada di sekolah. Menceritakan kembali hasil bacaan dan membaca terpadu. Hal ini menjadi strategi menumbuhkan budaya membaca yang divariasikan. Lebih lanjut, terdapat implementasi program-program lainnya yang perlu diketahui lebih lanjut melalui penelitian. Sebagai sekolah yang telah menjalankan program Gerakan Literasi Sekolah, hasilnya sudah dapat dilihat dan pelajari bagaimana mereka mengimplementasikan program tersebut di sekolahnya. Hal ini akan bermanfaat bagi sekolah lain yang ingin mengimplementasikan program tersebut. Semakin banyak sekolah yang menjalankan 
program GLS ini, maka diharapkan dapat meningkatkan kualitas manusia Indonesia secara keseluruhan.

Berdasarkan hasil wawancara pada tanggal 14 Januari 2021 dengan bapak Hardoyo, S.Pd. selaku kepala sekolah SDN 014 Kota Bangun, mengatakan bahwa program GLS ini telah dilaksanakan 1 tahun terakhir. Dengan menyediakan pojok baca untuk anak-anak membaca 15 menit sebelum memasuki pelajaran jam pertama merupakan tahap pembiasaan dari program GLS. Tetapi pada proses tahap pembiasaan masih ada guru yang enggan untuk melaksanakan kegiatan tersebut, dikarenakan guru lebih memikirkan mengejar materi yang akan diajarkan. Dari hal tersebut tampak bahwa program GLS di SDN 014 Kota Bangun masih memiliki kendala. Kendala lain yang juga terjadi yaitu kurangnya antusiasme siswa dalam kegiatan membaca. Berdasarkan pengakuan salah satu guru wali kelas mengatakan bahwa siswa masih kurang dalam minat membaca, masih banyak siswa yang terlihat main-main dengan temannya dari pada fokus membaca. Ketersediaan bacaan yang disukai anak-anak masih sangat minim sehingga siswa saling berebut untuk membaca buku yang disenangi, dalam hal ini pihak sekolah mengaku bahwa tahap proses pembiasaan membaca ini masih perlu peningkatan. Pihak sekolah masih mengusahakan memenuhi kebutuhan siswa.

Hal yang sama juga diterangkan pada penelitian yang telah dilakukan sebelumnya, yaitu menyatakan bahwa kurangnya sarana dan prasarana yang dimiliki sekolah sehingga menyulitkan pihak sekolah untuk melaksanakan semua tahapan Gerakan Literasi Sekolah yang telah dicanangkan pemerintah (Dafit \& Ramadan, 2020). Guru merasa kesulitan dalam melaksanakan program karena guru memiliki tanggung jawab lain yaitu mengajar dan kewajiban administrasi), selain itu guru merasakan waktu yang digunakan untuk pelaksanaan GLS ini menyita waktu pembelajaran siswa. Oleh karena itu, pihak-pihak terkait harus berupaya membangun pelaksanaan program ini dengan baik dengan melengkapi fasilitas, mengatur waktu yang tepat, dan memotivasi guru dalam pelaksanaan program literasi sekolah.

\section{METODE}

Penelitian ini menggunakan pendekatan kualitatif dengan metode analisis deskriptif. Metode analisis deskriptif digunakan dengan tujuan untuk mengetahui seperti apa implementasi gerakan literasi sekolah (Bungin, 2019). Pada penelitian ini, peneliti akan menerangkan kegiatan gerakan literasi sekolah di SDN 014 Kota Bangun. Penelitian ini lebih fokus kepada hasil pengamatan langsung dan wawancara terhadap responden yang telah ditetapkan dalam hal ini melibatkan kepala sekolah, guru wali kelas, dan beberapa siswa di SDN 014 Kota Bangun Kecamatan Tapung Hilir Kabupaten Kampar. Adapun lokasi penelitian ini akan dilaksanakan di SDN 014 Kota Bangun, Jalan 
Pendidikan Desa Kota Bangun Kecamatan Tapung Hilir Kabupaten Kampar. Penelitian ini dilaksanakan pada bulan Juni 2021 hingga lamanya durasi waktu penelitian ini dilakukan.

Teknik pengumpulan data yang digunakan oleh peneliti adalah observasi, wawancara, dan dokumentasi. Adapun pemeriksaan keabsahan data dalam penelitian ini dilakukan dengan cara triangulasi. Triangulasi dalam penelitian ini adalah triangulasi sumber dan triangulasi teknik. Dalam proses analisa data yang akan dilakukan yaitu menggunakan model interaktif. Aktivitas dalam analisis data dilakukan dengan reduksi data, penyajian data, dan menarik kesimpulan/verifikasi (Sugiono, 2019).

\section{HASIL DAN PEMBAHASAN}

\section{Pelaksanaan Program Gerakan Literasi Di SDN 014 Kota Bangun}

Kegiatan literasi di SDN 014 Kota Bangun mulanya diprakarsai oleh peraturan menteri pendidikan dan kebudayaan (Permendikbud) nomor 23 tahun 2015 tentang penumbuhan budi pekerti. Permendikbud ini diwujudkan dengan wajib membaca khususnya bagi siswa SD, SMP, atau SMA. Kementerian pendidikan dan kebudayaan mengembangkan gerakan literasi sekolah sebagai upaya untuk mengatasi minat baca yang rendah pada siswa Indonesia yang sampai saat ini gencar diperkenalkan dan dibudayakan diberbagai sekolah. Tidak terkecuali dengan SDN 014 Kota Bangun. Kegiatan literasi dirasa penting bagi SDN 014 Kota Bangun sebab literasi memiliki manfaat yang besar terhadap peserta didik, terlebih jika literasi menjadi budaya yang dibiasakan dan dikembangkan di sekolah.

Peneliti mewawancarai kepala sekolah yaitu bapak Hardoyo mengenai seperti apa program literasi pada umumnya yang dibangun di SDN 014 Kota Bangun, pada tanggal 05 Juli 2021. Beliau mengatakan bahwa literasi itu bukan hanya kemampuan membaca pada siswa, tetapi sebagai pintu utama untuk menggali keterampilan siswa yang diperlukan dalam kehidupan sehari-hari sehingga literasi sangat dibutuhkan siswa dan tidak bisa dilepaskan dari kemampuan berbahasa. Hal positif apapun bisa dilaksanakan selama itu meningkatkan dan mengembangkan potensi siswa sebagai dasar evaluasi atas kekurangan-kekurangan yang lama. Selain memang program pemerintah sedang digalakkan, beliau juga melihat positifnya banyak dan respon orang tua siswa sangat bagus, sehingga banyak positifnya dari literasi yang dilaksanakan. Bahkan ada yang menyumbangkan lebih dari 3 buku walaupun pihak sekolah menyarankan menyumbangkan 1 buku saja sebagai bentuk dukungan kepada sekolah, demi berkembangnya kegiatan literasi ini dan bukunya tidak ditentukan jenis buku yang harus dibawa untuk dibaca, namun buku tersebut harus sesuai dengan perkembangan anak-anak. 
Peneliti juga menggali informasi menurut guru kelas mengenai makna literasi yang sedang dibangun di SDN 014 Kota Bangun, dengan penjelasan ibu wali kelas Vb, yaitu Ibu Firayani pada tanggal 08 Juli 2021. Beliau mengatakan bahwa segala kegiatan itu sudah bisa disebut literasi, mulai dari membaca, menyampaikan, mengapresiasi karya seni, kemudian berhitung dalam kegiatan seharihari juga berliterasi. Untuk mendapatkan keabsahan data pada penelitian ini, peneliti juga turut melakukan wawancara kepada salah satu perwakilan siswa SDN 014 Kota Bangun. Dalam hal ini peneliti memilih siswa yang kebetulan sedang menjalankan program literasi di sekolah tersebut, yaitu Kayla Putri pada tanggal 17 Juli 2021. Menurutnya, literasi adalah pembiasaan yang berkarakter dan menambah wawasan.

Selain pembiasaan membaca, pembudayaan literasi juga didukung dengan sarana penunjang kegiatan literasi seperti majalah dinding dan tulisan-tulisan yang mengunggah minat siswa untuk membaca. Berdasarkan wawancara dengan kepala sekolah, yaitu Bapak Hardoyo pada tanggal 05 Juli 2021, beliau mengungkapkan bahwa SDN 014 Kota Bangun mendukung kegiatan literasi dengan turut serta menghidupkan mading-mading di sekolah. Sebagaimana yang diungkapkan sebenarnya, banyak tujuan yang ingin dicapai dalam pelaksanaan pembudayaan literasi sekolah yang dikemas dalam program gerakan literasi, diantaranya bermula dari keresahan bangsa terhadap minat baca yang rendah dimata dunia. Untuk itu, gerakan pembudayaan membaca dapat meningkatkan wawasan siswa, serta sebagai salah satu cara yang dapat dilakukan dalam pembentukan karakter siswa.

Berdasarkan hasil wawancara dengan kepala sekolah di atas, mengungkapkan bahwa umumnya guru berpandangan bahwa tujuan dari adanya gerakan literasi khususnya di SDN 014 Kota Bangun yaitu untuk membiasakan anak membaca dan menambah wawasan serta dapat mengamalkan apa yang dibacanya untuk kehidupannya. Lebih lanjut, hasil observasi dan wawancara yang dilakukan melalui kepala sekolah, pada umumnya tujuan kegiatan literasi di SDN 014 Kota Bangun adalah sebagai berikut:

a. Membantu meningkatkan pengetahuan anak

b. Meningkatkan nilai kepribadian seseorang melalui kegiatan membaca dan menulis

c. Meningkatkan kemampuan seseorang dalam memberikan penilaian kritis terhadap suatu karya

Kepala sekolah SDN 014 Kota Bangun juga mengharapkan anak bisa memahami inti dari apa yang mereka baca dan bisa mengamalkan makna yang terdapat dalam bacaan tersebut, serta dapat mempraktikkan dalam kehidupan mereka sehari-hari. Intinya mereka harus mampu memahami apa yang mereka baca tidak hanya di luar saja, melainkan menyerap segala intisari yang baik, sehigga dapat mengembangkan wawasan secara luas karena banyak manfaat yang dapat diperoleh dari pembiasaan membaca. Dengan membiasakan diri untuk membaca sejak dini, berarti secara tidak 
langsung mendisiplinkan diri dalam menggali wawasan-wawasan baru setiap hari. Buku bacaan memang memiliki pengaruh dalam membentuk karakter siswa, terlebih jika buku yang dibaca mengandung nilai-nilai keteladanan.

\section{Jenis Program Kegiatan Literasi Di SDN 014 Kota Bangun}

\section{Kegiatan Selasa Literasi}

Kegiatan Selasa literasi dilakukan hari selasa khusus untuk siswa kelas rendah, yaitu kelas 1-3 di mana siswa-siswi yang akan menjadi objek bercerita baik di lapangan ataupun di kelas yang akan disesuaikan kondisi padahari tesebut. Hal pertama yang dilakukan adalah seluruh siswa membaca 15 menit, kemudian akan diminta 1 orang perwakilan sebelum jam pelajaran dimulai untuk maju kedepan akan dipanggil atau dipilih guru wali kelas masing-masing dan diberi waktu maksimal 5 menit untuk menceritakan yang mereka baca dan menyimpulkan sendiri makna, serta mengaitkannya dalam kehidupan sehari hari. Dari hasil observasi pada kegiatan selasa literasi, siswa sedang membaca buku cerita bergambar dengan judul Pajak Kita. Kegiatan itu sedang berlangsung di dalam kelas dikarenakan cuaca sedang hujan.

Dari hasil wawancara guru kelas V-a pada tanggal 08 juli 2021 mengatakan bahwa terdapat permasalahan dalam kegiatan ini, seperti siswa kelas rendah masih sangat minim dalam kelancaran membaca, sehingga masih membutuhkan bimbingan dari guru. Oleh karena itu, kegiatan ini sangat jarang dilakukan oleh kelas 1 dan 2. Biasanya kegiatan ini akan diganti dengan kegiatan lain seperti guru yang bercerita dan siswa yang mendengarkan.

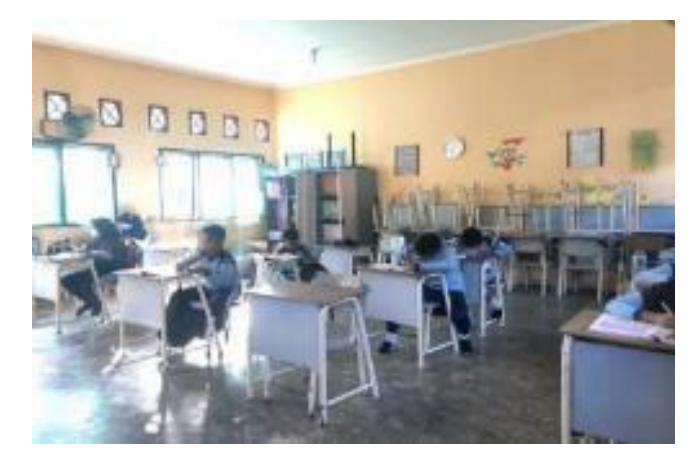

Gambar 1. Kegiatan Selasa Literasi

\section{Kegiatan Rabu Literasi}

Kegiatan Rabu Literasi dilakukan khusus hari rabu untuk kelas tinggi yaitu kelas 4-6. Siswa memulai dengan membaca 15 menit kemudian mendengarkan guru kelas yang memberikan materi. Buku yang dibaca oleh siswa kelas tinggi biasanya dibagi sesuai giliran, baik buku fiksi atau non fiksi. Siswa diminta untuk mendengarkan guru dalam menyampaikan materi baik berupa motivasi, 
keteladanan, pencerahan, serta mengkaitkan dengan kehidupan sehari-hari untuk menumbuhkembangkan karakter siswa. Dari hasil observasi, rabu literasi dilakukan di kelas tinggi dengan membaca 15 menit buku dengan judul Si Anak Pemberani. Dari buku tersebut guru akan menyampaikan sebuah apersepsi tentang pentingnya berani sehingga anak termotivasi dari materi literasi tersebut dan dapat mengapalikasikan dalam kehidupan sehari-hari. Biasanya siswa diminta untuk menyimak agar dapat menuliskan kembali apa yang telah disampaikan oleh guru kelas masingmasing dan akan dikumpul atau dievaluasi secara langsung.

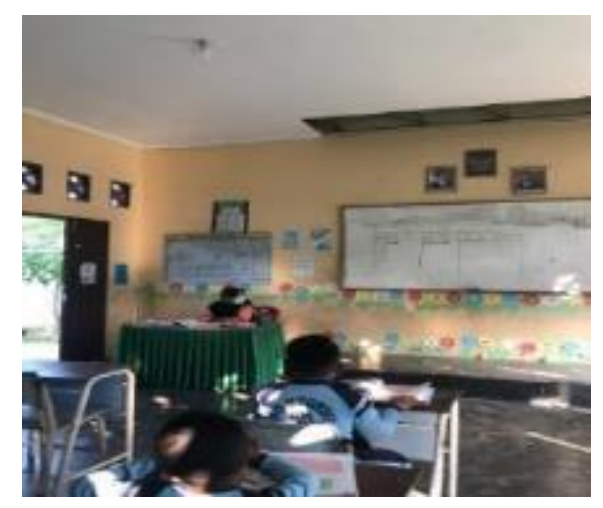

Gambar 2. Kegiatan Rabu Literasi

Hasil wawancara dengan guru kelas, yaitu Ibu Firayani pada tanggal 11 Juli 2021, beliau mengatakan bahwa permasalahan pada kegiatan di kelas tinggi adalah siswa masih banyak ketinggalan materi ajar, dalam arti ada guru yang tidak melaksanakan kegiatan tersebut dikarenakan alokasi waktu yang kurang, khususnya pada siswa kelas 6. Hal tersebut karena siswa lebih berfokus pada pembelajaran wajib, sehingga kelas tersebut sangat jarang melaksanakan kegiatan rabu literasi. Dalam permasalahan lain, siswa masih suka bercerita sendiri disaat guru menyampaikan materi terkait kegiatan literasi. Oleh karena itu, sekolah juga masih menegakkan secara rutin kegiatan literasi salah satunya adalah pagi motivasi.

\section{Kegiatan Literasi Pagi Motivasi}

Kegiatan Literasi Pagi Motivasi adalah kegiatan yang mengajak siswa untuk dapat mencintai buku. Dalam kegiatan ini diwajibkan bagi seluruh siswa SDN 014 karena aktivitas ini menuntun siswa untuk terbiasa membaca. Dari hasil observasi, dalam seminggu siswa diminta dapat membaca minimal 3 buku di rumah masing-masing. Setiap siswa diminta untuk mencatat judul buku dan hasil bacaan yang telah siswa baca, kemudian setiap hari jum'at pagi kegiatan literasi pagi motivasi dilakukan. Pertama, siswa diminta untuk mengumpulkan semua catatan dan akan dibahas satu persatu. Siswa diberi pertanyaan terkait kegiatan literasi yang telah dilaksanakan sebelumnya dan berbagi cerita kepada teman sekelas dalam bentuk lisan, kegiatan ini bertujuan untuk banyak mengoreksi kegiatan siswa selama kegiatan literasi berlangsung. Dengan harapan guru bukan hanya 
materi yang didapatkan siswa dari buku-buku non pelajaran, literasi pagi motivasi juga bisa dalam bentuk hasil pengalaman hidup siswa itu sendiri dan bisa mendapatkan hikmah untuk kedepannya. Namun dalam kegiatan ini menurut hasil wawancara kepala sekolah, yaitu Bapak Hardoyo pada tanggal 05 Juli 2021 mengatakan bahwa kegiatan ini tidak berjalan sesuai dengan semestinya dikarenakan keterbatasan waktu akibat pandemi covid-19.

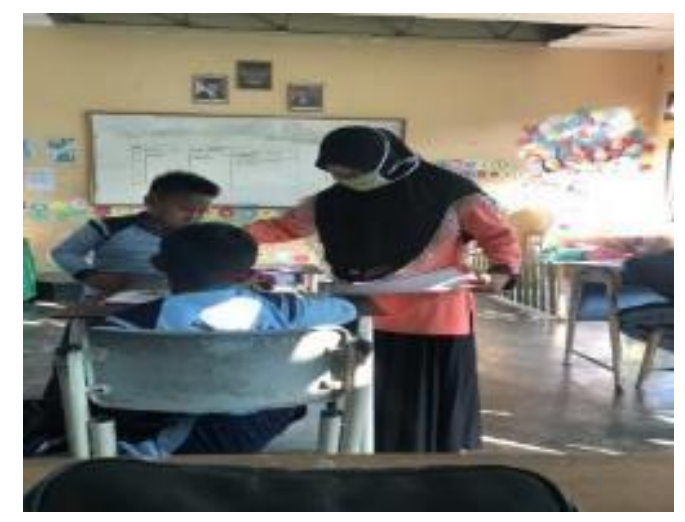

Gambar 3. Kegiatan Literasi Pagi Motivasi

\section{Kegiatan Literasi Membaca Senyap}

Kegiatan Literasi Membaca Senyap dilakukan di perpustakaan, pada hari sabtu sesuai jam yang ditentukan oleh sekolah. Program ini merupakan kegiatan siswa untuk mengasah kemampuan membaca. Membaca senyap akan dipandu oleh guru wali kelas masing-masing dan akan dibagi dalam 1 kelompok yang terdiri dari 4-5 siswa. Setiap siswa boleh memilih bahan bacaan yang mereka minati. Pada kegiatan ini siswa membaca dalam hati masing-masing atau membaca senyap. Membaca senyap dilakukan untuk sebagai kegiatan kunjungan perpustakaan secara rutin. Kegiatan ini tujukan pada semua kelas, dan waktu yang diberikan adalah 20 menit. Kemudian setelah waktu habis siswa akan diminta untuk melanjutkan kegiatan belajar mengajar seperti biasa di dalam kelas. Sekolah perlu menerapkan strategi membaca senyap agar terbebas dari gangguan suara-suara yang akan mengganggu konsentrasi siswa dalam memahami bahan bacaan.

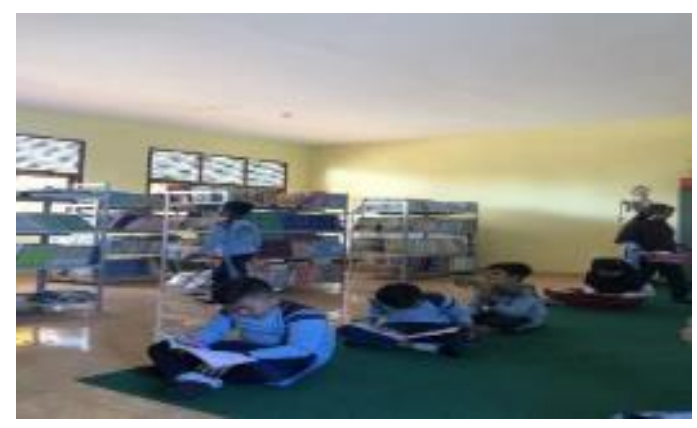

Gambar 4. Kegiatan Literasi Membaca Senyap 


\section{Pengadaan Perpustakaan sebagai Sumber Literasi}

Bapak Hardoyo selaku kepala sekolah pada tanggal 05 Juli 2021, mengatakan bahwa apapun bisa dilaksanakan selama hal itu bisa meningkatkan dan mengembangkan potensi siswa sebagai dasar evaluasi atas kekurangan-kekurangan sebelumnya. Sekolah mendapat respon positif dari masyarakat, sehingga pihaknya membuka kegiatan pengadaan perpustakaan sebagai sumber literasi yang ditujukan kepada public, baik dari siswa, orang tua, atau masyarakat lainnya. Bahkan ada yang menyumbangkan lebih dari 3 buku. Namun pihaknya menyarankan buku tersebut harus sesuai dengan perkembangan anak-anak. Kegiatan pengumpulan buku juga dilakukan secara rutin setiap 2 bulan sekali, untuk kemudian akan disusun dengan rapi diperpustakaan sesuai dengan bagian-bagaiannya. Buku tersebut juga akan disalurkan setiap kelas untuk persediakan buku koleksi pojok baca. Jenisjenis buku yang telah terkumpul di perpustakaan adalah sastra tradisional, komik, buku bergambar, buku informatif, buku biografi, bukun realistis, fantasi modern, dan lain-lainnya.

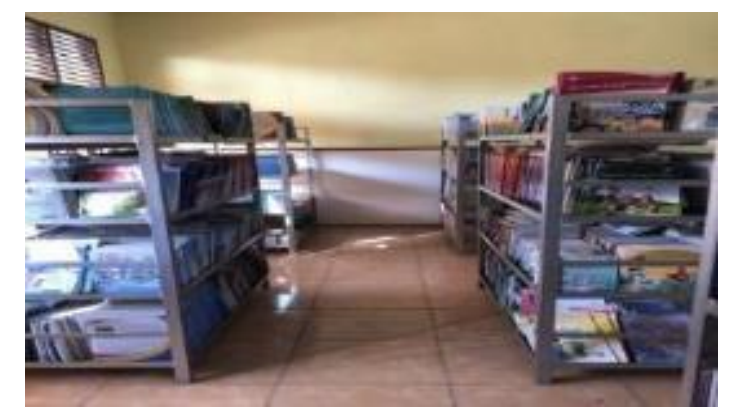

Gambar 5. Inventaris Perpustakaan SDN 014 Kota Bangun

\section{Menciptakan Lingkungan Literasi}

Berdasarkan wawancara dengan kepala sekolah pada tanggal 05 Juli 2021, beliau mengungkapkan bahwa SDN 014 Kota Bangun mendukung kegiatan literasi dengan menciptakan lingkungan literasi. Kegiatan yang disediakan sekolah seperti menghidupkan mading-mading di sekolah pada setiap kelas. Dalam hal ini diatur oleh seluruh guru kelas masing-masing. Dalam kegiatan ini, tema akan ditentukan sekolah dan akan menjadi agenda rutin sebulan sekali yang harus ganti. Kegiatan lainnya seperti penempelan poster-poster menarik, baik untuk himbauan, ajakan, atau larangan yang ditempel di dalam kelas maupun di lingkungan luar lainnya.

Seperti halnya yang disampaikan oleh guru kelas, yaitu Ibu Patimah pada tanggal 08 Juli 2021, mengatakan bahwa salah satu cara yang dapat dilakukan dalam pembentukan karakter siswa adalah dengan membuat mading. Mading ini sebagai upaya penyediaan sumber informasi yang mudah diakses di luar perpustakaan, mading ini berisi informasi kegiatan dari perpustakaan, serta tempat penyaluran bakat-bakat siswa, tidak hanya gambar berisi seruan. 


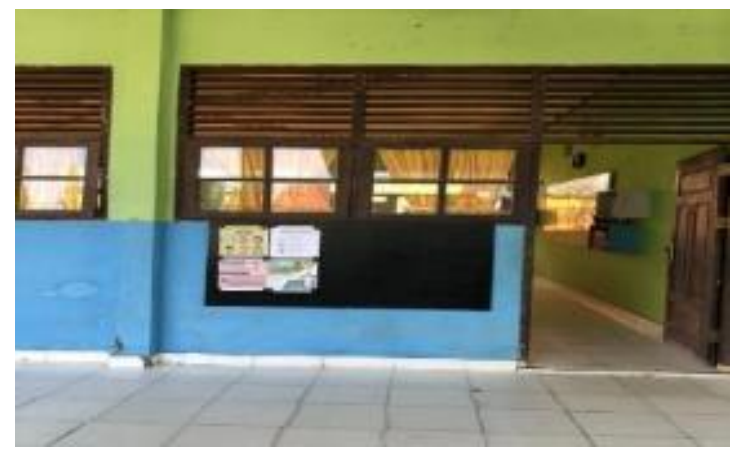

Gambar 6. Mading di SDN 014 Kota Bangun

Dari hasil observasi juga ditemukan mading kelas yang menempelkan kreativitas siswa-siswi yang bervariasi, seperti pohon literasi yang berisikan pengetahuan atau gambar pahlawan. Sekolah sudah menyediakan mading di setiap kelas, namun masih ada mading kelas yang kosong dan tidak berisikan bacaan atau gambar-gambar yang menarik.

\section{Pojok Baca Kelas}

Untuk menunjang kebutuhan bahan bacaan yang ada di SDN 014 Kota Bangun, pada setiap kelasnya terdapat perpustakaan mini atau disebut dengan pojok membaca, di mana tempat tersebut adalah tempat untuk mendukung siswa ketika ingin membaca buku. Dari hasil observasi, pojok baca sudah ada setiap kelas. Kegiatan pojok baca di kelas dilakukan pada jam istirahat dan tidak terikat waktu. Hasil wawancara guru kelas V-b mengatakan bahwa kegiatan pojok baca ini tetap menjadi evaluasi guru kelas karena bagi siswa yang memanfaatkan pojok baca akan memiliki catatan baik dan akan diapresiasi oleh guru kelas masing-masing sesuai agenda yang telah ditentukan guru. Catatan tersebut hanya dimiliki guru, di mana siswa yang telah membaca akan dicatat.

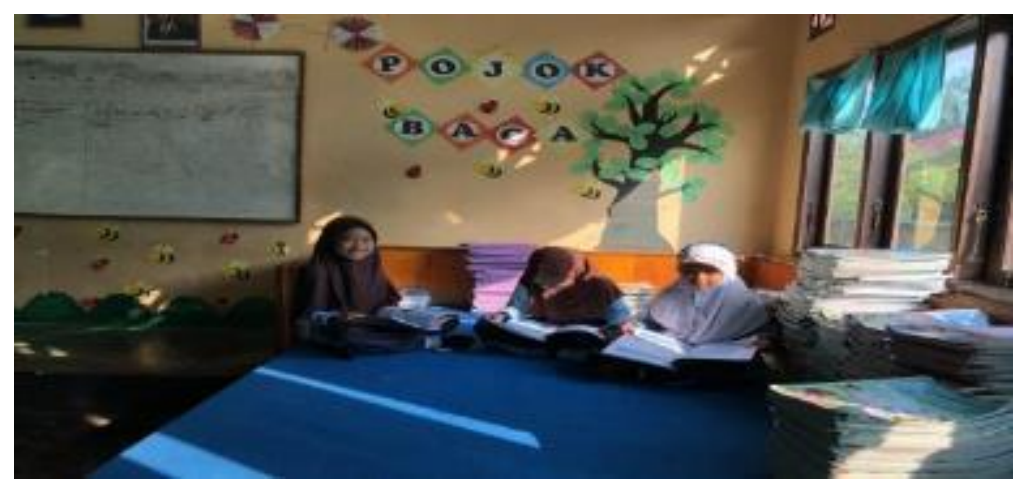

Gambar 7. Pojok Baca Kelas

\section{Buku yang Mendukung Program Literasi Di SDN 014 Kota Bangun}

Dari hasil pengamatan, jenis buku yang dibawa siswa tidak ditentukan jenisnya. Koleksi literatur anak di pojok membaca memiliki jenis yang berbeda-beda, diantaranya: 


\section{a. Sastra Tradisional}

Cerita-cerita yang termasuk sastra tradisional adalah cerita rakyat yang meliputi legenda, mite, dan dongeng. Koleksi sastra tradisional biasa digunakan oleh siswa-siswi untuk lebih mengenal cerita rakyat dari suatu daerah.

b. Komik

Buku bacaan yang menyerupai cerita menggambar dan menggabungkan sedikitnya teks serta terdiri dari berbagai bentuk untuk menunjukkan berbagai maksud. Komik sering dimanfaatkan oleh siswa kelas bawah dikarenakan alur cerita yang mudah dipahami serta sedikitnya teks yang terdapat dalam komik.

Buku ini berisikan gambar untuk membentuk suatu makna dari cerita. Ada beberapa macam picture book antara lain, buku alphabet, buku berhitung, buku informasi yang berisi gambar- gambar dengan sedikit tulisan.

\section{d. Buku informatif}

Buku informasi untuk anak-anak pun diberi foto dan ilustrasi, buku dikemas dalam bentuk cerita namun juga harus akurat, otentik, dan menggunakan fakta-fakta. Pojok membaca kelas sudah mempunyai koleksi buku informatif seperti sains, buku science fiction, buku multicultural, buku social science. Buku informatif di perpustakaan sering digunakan oleh pengguna dalam hal pencarian informasi atau melakukan eksperimen ketika akan mengikuti kegiatan science fair.

e. Buku biografi

Jenis buku ini berisi tentang kisah para tokoh atau pahlawan. Biografi ini sebagai bentuk pemenuhan kebutuhan siswa untuk mengetahui tokoh-tokoh besar dan perannya masing-masing. Beberapa jenis literatur yang telah disebutkan di atas, siswa dapat menggunakannya sebagai bahan pemanfaatan literasi informasi apapun. Pemanfaatan koleksi fiksi di suatu perpustakaan sangat penting bagi siswa karena karya fiksi mampu memberikan hiburan segar dan juga memberikan inspirasi baru bagi para pembaca, serta mengapresiasikannya sesuai dengan kadar kemampuan dan imajinasi para siswa. Dengan membaca karya fiksi, siswa mendapatkan inspirasi dan diajarkan untuk mempunyai khayalan atau angan-angan agar nantinya dapat dituangkan ke dalam bentuk tulisan sesuai dengan imajinasinya. Selain pemanfaatan secara fiksi, siswa juga dapat mengambil banyak manfaat dari sumber literasi non-fiksi.

\section{f. Fiksi realistis}

Fiksi realistis yaitu fiksi yang diset dimasa modern dan dapat dibayangkan terjadi pada kehidupan manusia yang nyata dan ceritanya terjadi di dunia. Fiksi realistis biasanya bercerita tentang petualangan detektif, misteri, humor, cerita tentang masalah pribadi seperti kebahagiaan, kesedihan dan sebagainya. 


\section{g. Fantasi modern}

Cerita berupa dongeng-dongeng modern yang banyak mengambil elemen-elemen cerita rakyat. Koleksi fantasi modern sudah ada di pojok membaca dan pemanfaatannya oleh siswa sudah terlihat. Namun, belum banyak jenis buku fantasi modern di pojok membaca ini.

\section{Faktor Pendukung dan Penghambat Pelaksanaan Program Literasi Di SDN 014 Kota Bangun}

Kegiatan literasi yang dilaksanakan di SDN 014 Kota Bangun Kecamatan Tapung Hilir Kabupaten Kampar berdasarkan pada Permendikbud Nomor 21 Tahun 2015 tentang penumbuhan budi pekerti dan keputusan rapat kerja. Pada awalnya kegiatan literasi di SDN 014 Kota Bangun ini dilakukan secara klasikal di lapangan yang dilakukan pada setiap Selasa dan Rabu pagi yang biasa disebut dengan Reading Morning. Namun kegiatan literasi juga dilaksanakan setiap hari 15 menit sebelum pembelajaran dimulai di dalam kelas masing masing.

Dalam merancang sebuah program kegiatan tentunya telah melalui berbagai persiapan perencanaan, namun berjalannya program yang dicanangkan tidak terlepas dari berbagai faktor yang dapat mendukung atau menghambat pelaksanaan program tersebut. Kegiatan literasi yang dilaksanakan di SDN 014 Kota Bangun, terutama yang dilaksanakan di kelas tinggi juga tidak terlepas dari faktor-faktor yang dapat mendukung atau menghambat. Faktor-faktor yang dapat mendukung dan menghambat budaya literasi yang dikemas dalam Kegiatan Literasi di SDN 014 Kota Bangun yaitu sebagai berikut:

\section{Faktor Pendukung}

Program yang digalakkan oleh pemerintah sangat didukung oleh sekolah. Para orang tua sangat memfasilitasi anak-anaknya ketika berkaitan dengan membaca buku. Mnurut mereka, kegiatan literasi adalah kegiatan positif yang dapat menumbuhkan minat membaca anak. Orang tua siswa juga memiliki peran dalam hal pengadaan sumber buku. Kerjasama yang baik antara sekolah dan orang tua penting dilakukan, sebab dalam membiasakan membaca siswa perlu adanya kesamaan pembiasaan dari orang tua serta pihak sekolah. Dalam pengadaan sumber buku, orang tua siswa menjadi salah satu sumber pengadaan buku-buku bacaan anak. Keterlibatan orang tua berfungsi sebagai filter dalam pemilihan buku-buku yang layak bagi anak, selain itu juga agar terjalinnya kerjasama yang baik dalam memperoleh tujuan yang sama yaitu membentuk karakter siswa menjadi lebih baik.

Buku-buku cerita di perpustakaan SDN 014 Kota Bangun umumnya berasal dari penyediaan pihak sekolah. Setiap tahunnya buku-buku bacaan siswa terus beregenerasi dengan buku-buku baru sehingga siswa dapat membaca buku-buku cerita yang sesuai dengan perkembangan zaman. Selain buku-buku yang ada di perpustakaan, orang tua siswa juga mendukung pengadaan buku untuk pojok baca di setiap kelas. Sebelumnya orang tua siswa memang dihimbau untuk membawa buku-buku 614 
bacaan yang sesuai dengan usia anak. Bahkan ada orang tua yang menyumbangkan lebih dari 3 buku walaupun pihak sekolah menyarankan menyumbangkan 1 buku untuk disumbangkan untuk support sekolah demi berkembangnya kegiatan literasi ini dan bukunya.

Berdasarkan berbagai data yang peneliti dapatkan, peneliti menyimpulkan bahwa orang tua siswa merupakan faktor pendukung budaya literasi yang ada di SDN 014 Kota Bangun. Peran orang tua memiliki kepedulian terhadap peningkatan minat baca anak dengan menyumbangkan buku-buku bacaan. Dengan terjalinnya kerjasama antara sekolah dengan orang tua siswa yang saling bersinergi, diharapkan dapat terwujudnya budaya sekolah yang kaya literasi.

\section{Faktor Penghambat}

Selain faktor yang mendukung terlaksananya budaya literasi di SDN 014 Kota Bangun, juga terdapat faktor yang justru menghambat. Ada beberapa faktor penghambat kegiatan literasi di SDN 014 Kota Bangun diantaranya;

a. Sarana dan prasarana penunjang kegiatan literasi, seperti keterbatasan lapangan yang terkendala saat hujan turun akan menggenangi lingkungan sekolah sehingga Selasa-Rabu literasi tidak bisa dijalankan. Selain itu, ruangan perpustakaan yang kurang memadai untuk menampung bukubuku yang tersedia di sekolah.

b. Partisipasi sebagian guru merupakan komponen utama dalam pelaksanaan kegiatan literasi di sekolah. Pelaksanaan literasi tidak akan terwujud tanpa adanya guru, oleh sebab itu peran guru sangat penting dalam program literasi sekolah. Tugas dan tanggung jawab guru mengarahkan dan membentuk perilaku dan akhlak peserta didik agar menjadi lebih baik.

c. Keaktifan sebahagian kelas, setelah dicanangkan kegiatan literasi guru selalu berusaha untuk memaksimalkan pembelajaran dengan memasukkan kegiatan-kegiatan literasi di sekolah, tetapi setelah diteliti, belum adanya sebagian kesadaran dari siswa untuk melaksanakan kegiatan literasi secara mandiri, sehingga karakter siswa belum berbentuk secara maksimal dan belum menjadi budaya sekolah.

\section{KESIMPULAN}

Berdasarkan hasil temuan pada penelitian ini, dapat disimpulkan mengenai pelaksanaan program Gerakan Literasi Sekolah (GLS) di SDN 014 Kota Bangun Kecamatan Tapung Hilir Kabupaten Kampar di mana berbagai upaya dilakukan pihak sekolah dalam pelaksanaan program literasi yang diwujudkan dalam berbagai program penunjang literasi seperti, Selasa Literasi, Rabu Literasi, Pagi Motivasi, Kegiatan Membaca Senyap, Penyediaan Perpustakaan sebagai Sumber 
Literasi, Penyediaan Pojok Baca Setiap Kelas, dan Mading. Kegiatan literasi di SDN 014 Kota Bangun belum dapat dikatakan sebagai kebiasaan yang membudaya, akan tetapi sudah termasuk dalam upaya yang menumbuhkan budaya literasi. Meskipun sudah terdapat upaya lain berupa pengembangan dan pembelajaran literasi dalam setiap mata pelajaran sebagai tahap lanjutan dari pelaksanaan program literasi sekolah yang dilakukan oleh Guru, namun hal itu belum dilakukan secara konsisten dan berkelanjutan, sehingga dapat dikatakan pelaksanaan program literasi di SDN 014 Kota Bangun masih dalam tahap pembiasaan/penumbuhan minat. Terdapat faktor-faktor pendukung dalam program GLS ini, antara lain mengenai kerjasama yang baik antara sekolah dan orang tua, bahkan orang tua juga ikut memberi masukan dalam pembuatan pojok baca. Faktor penghambat dalam kegiatan GLS antara lain, yaitu mengenai sarana dan prasarana penunjang kegiatan literasi, masalah partisipasi sebahagian guru, dan keaktifan sebahagian kelas.

\section{DAFTAR PUSTAKA}

Anggraeni, P. R. (2019). Implementasi Kebijakan Literasi Sekolah Guna Peningkatan Karakter Gemar Membaca. Indonesian Journal of Sociology, Education, and Development, 132-142.

Bungin, B. (2019). Metodologi Penelitian Kualitatif. Depok: Rajawali Pers.

Dafit, F., \& Ramadan, Z. H. (2020). Pelaksanaan Program Gerakan Literasi Sekolah (GLS) di Sekolah Dasar. Jurnal Basicedu, 1429-1437.

Hidayah, L. (2017). Implementasi budaya literasi di sekolah dasar melalui optimalisasi perpustakaan: Studi kasus di Sekolah Dasar Negeri di Surabaya. JU-ke (Jurnal Ketahanan Pangan), 48-58.

Kemendikbud. 2016. Panduan Gerakan Literasi sekolah di Sekolah Dasar: Direktorat Jendral Pendidikan Dasar dan Menengah Kementrian Pendidikan dan Kebudayaan Republik Indonesia Kemendikbud. 2017. Panduan Penyelenggaraan Program Gerakan Indonesia Membaca: Direktorat Jendral Pendidikan Anak Usia Dini dan Pendidikan Masyarakat

Setyawan, D., \& Gusdian, R. I. (2020). Penguatan Habitus Literasi: Sebuah Cara Pendampingan Tim Literasi Sekolah (TLS). E-DIMAS: Jurnal Pengabdian Kepada Masyarakat, 299-306.

Sugiyono. (2019). Metode Penelitian Pendidikan (Pendekatan Kuantitatif, Kualitatif dan R\&D). Bandung: Alfabeta.

Wiedarti, P. (2016). Desain Induk Gerakan Literasi Sekolah. Jakarta: Ditjen Dikdasmen Kementrian Pendidikan dan Kebudayaan RI. 